\title{
Legislative Investigation of Un-American Activities Exhibit A: The Tenney Committee
}

\author{
Lawrence A. Harper*
}

CHARges and countercharges fill the air and cover the pages of the press.

Senator Benton presents sworn charges against Senator McCarthy and the subcommittee votes to hear them. An article in Time, which few if any suspect of communistic leanings, presents data concerning forged pictures, innuendos and half truths which give rise to little confidence in "McCarthyism." Yet we know that Alger Hiss was convicted of perjuring himself, that Fuchs and others have confessed to betraying our atomic secrets. What is a conscientious American to believe? How should he act?

Legislative investigating committees are decried and defended. The courts have recognized that they possess extraordinary powers because of the lawmakers' need for knowledge in enacting legislation. Yet investigating committees have been denounced on the grounds that they seek to try individuals, a task for which they are not equipped-one traditionally assigned to courts of law rather than to investigating committees.

The subject deserves the attention of members of the bar. As citizens they wish the country to be protected from subversive elements. As attorneys they know the importance of proper procedure and the dangers of arbitrary short-cuts, however noble the intent. As professional men instead of artisans they stand ready to assume larger public responsibilities than that of merely earning a living. ${ }^{1}$ Thus they will do well to review the record of one of California's most publicized investigating committees as reported by Professor Edward L. Barrett, Jr., a member of the California State Bar and professor of constitutional law at the University of California, Berkeley.

\section{Professor Barrett's Book: The Tenney Committee ${ }^{2}$}

Professor Barrett is a safe guide. His youth and college education in a small town in northern Utah isolated him from "communist contagion or even awareness of the problem during the umited-front-against-fascism

* Professor of American History, University of California, Berkeley.

${ }_{1}^{1}$ This point was stressed by Milton Katz at the recent dinner of the U.C. Law School Association, Oct. 19, 1951.

2 Barpett, Edward L., JR., The Tenney Comraittee. Legislative Investigation of Subversive Activttres in California. Ithaca, New York, Cornell Univ. Press, 1951. xi, 400 pp. $\$ 5.00$.

This is one of a series of studies on civil liberties being sponsored by Cornell University under a grant by the Rockefeller Foundation. The first report was Security, Loyalty and Science (1950) by Professor Walter Gellhorn of the Columbia University School of Law. Other volumes include monographs on the control of subversive activities in New York by Lawrence $H$. Chamberlain, Dean of the Columbia Law College; one on the state of Washington by Vern 
period" and naval service removed him "from temptation during the period of wartime collaboration with Russia and Russian sympathizers." $\mathrm{He}$ is "opposed to communism both in theory and its practice by the international Communist Party." A non-joiner by nature, he has not been connected with any of the organizations listed by the Tenney committee as subversive "if menibership on the Executive Committee of the American Civil Liberties Union of northern California and a subscription to Consumer Reports can be overlooked."3

His book, unlike so many on similar topics, avoids sensationalism. It reflects his legal training. The recital is calm; the emphasis rests on facts, buttressed by frequent excerpts from committee hearings and reports. The first chapters describe the beginning of legislative investigation of subversive activities in California, the origin of the Tenney committee, the various hearings it held and the reports it rendered. The last chapters recount the committee's legislative program, tell of Senator Tenney's ouster as chairman and give Professor Barrett's appraisal of the committee's work. Two appendixes provide first a committee list of communist front organizations and second the replies by certain individuals to charges made in the 1949 report.

More than two liundred pages between are devoted to accounts of the committee's investigations of the Japanese problem, the Zoot-Suit riots in Los Angeles, and local politics in Richmond and in Fairfax, as well as the experiences before the committee of Emmet Lavery, the playwright, Mrs. Frederic March, the actress (better known by her stage name, Florence Eldridge), and Judge Leon R. Yankwich of the United States District Court. Other chapters describe the attempts by the northern California branch of the American Civil Liberties Union and the Institute for Democratic Education to refute charges made against them, the committee's relations with the press and its investigations of the schools, with special reference to the UCLA Writers' Congress, the Hollywood Quarterly, the California Labor School and the People's Educational Center, the University IMCA in Berkeley, the Canoga Park High School in Los Angeles, and sex instruction as given in high school at Chico.

The episodes discussed are necessarily limited. Their choice has been "in part fortuitous, in part deliberate." The full transcripts of committee hearings have not been available. Thus the willingness of individuals involved to supply copies and to cooperate in providing background material helped to determine what was imcluded. In other cases "the choice has been

Countryman of the Yale Law School; a volume on the House Committee on Un-American Activities by Professor Robert K. Carr of Dartmouth College; one on the President's loyalty program and the summary dismissal statutes by Miss Eleanor Bontecou, formerly an attorney . in the Department of Justice; a general survey of state programs for the control of subversive activities by several scholars writing under Professor Gellhorn's editorship, and a final report summarizing the findings of all the studies.

Other recent publications concerning the general subject include Congressional Investigations. A Symposium, 18 U. of CHr. L. REv., Spring (1951); Civil Rights in America, 275 ANAATs (May) 1951; Barth, The Loyalty of Free Men (1951); Johnsen, Investigating Powzes OF Congress (1951).

3 BARRETT at $x$-xi. 
made because the particular episodes appear best to illustrate the philosophy and methods of the committee or because as a result of widespread publicity they have formed the bases for public opinion concerning it." "4

The subjective reactions of the author may have influenced his selection of the material quoted. There are more quotations from editorials in the San Francisco Chronicle, the San Francisco News, the Los Angeles Daily News and the Sacramento Bee criticizing the committee than from the Alert, the Hollywood Citizen-News, or the Los Angeles Times in its support. Yet Professor Barrett does not join those who attack Senator Tenney as a malevolent reactionary. His impression "is that Tenney and the other members of the committee have been honestly and sincerely convinced of the justice of their cause and of the necessity of their work to preserve the state from the dangers of the international communist movement.... People who know him well, however much they deplore his methods, credit him with complete sincerety in this work."

As befits a professor of constitutional law, Barrett sets a standard for judging the committee's work to which all good Americans nay subscribe: what is the ability of the legislative committee investigating subversive activities "to reduce the influence and effectiveness of totalitarian groups without seriously endangering democratic pressures for improvement of the economic and social structure of our country." 6

\section{Conflicting Views About Handling the Communist Menace}

Firmly convinced that a world-wide communist conspiracy threatened Califorma, the Temiey committee sought "to expose and isolate communists."It believed that "while small in number they are great in influence." The presence of a Communist in an organization causes it to become subversive. "When a trusted communist functionary appears as a member of the Board of Directors of an organization, the communist character and control of the group is firmly established." Thus no loyal American should associate with a suspect organization. Even if not himself contaminated he would lend an air of respectability to it which would help entrap others to join. ${ }^{7}$

The committee itself believed "that subversive organizations wither and die under the penetrating searchlight of publicity." "The Los Angeles Times declared that the work of the committee would force the "liberal" faddists and suckers in Hollywood to be more cautious in opening their purses or lending their names to organizations. Listing their names is a sharp blow which "may cut some of the golden sinews of the Communist Party and its fronts .... Now such a contribution is no longer a private matter. It can be audited by public opinion."

4 BARRETT at $x$.

5 Id. at 334 .

6 Id. at $\mathrm{xi}$.

TId. at $343,335,336$.

8 Id. at 280 .

9 Id. at 289, quoting from "Suckers Always Pay in the End" (editorial), L. A. Times, June 10,1949, p. 4 , cols. 1,2 . 
The committee sought to banish from all normal community life an individual believed by it to be a Communist or fellow traveler. As stated by Professor Barrett "the objective was to quarantine him as though he were infected with smallpox. Efforts were nuade to prevent association with him, to forbid lawyers to defend him in his troubles with the law, and to cause his employer to discharge him and his union to expel hini. People were warned that they should not rent hin a hall for a meeting, or join any organization of which he was a member, or read any book or attend any play or motion picture written by him, or even espouse any cause espoused by him."10

A different point of view was expressed by Emmet Lavery, the President of the Screen Writers Guild, a group "that has never had a political test for nuembership." Thanks to his efforts "to prevent either the right or the left from using the Guild for its own purposes," he took "blows from both sides." Denounced in a Tenney report as "a faithful fellow-traveler" whose record "indicates either a deep sympathy for the Conumunist movement or an amazing stupidity which is hardly conpatible with his background and education," he was also bitterly assailed for testifying before the House Committee in a panuphlet entitled "The Time of the Toad" by Mr. Dalton Trumbo, one of the ten Hollywood writers who did not testify and were facing contempt proceedings. ${ }^{11}$

His answer to the communist and Marxian philosophy is to have a better philosophy. As he stated to the committee in 1946:12

If we confine our opposition to communism to public speeclies and public crusades we simply expose ourselves to the dangers that Hitler brought about in Germany where you arbitrarily divide sections of the community, align group against group. You face the futility of trying to decide who is a Communist and who is not and what you mean by communism ... I believe the challenge is to get out and work in the market place and live a truly American life.

Mr. Lavery stressed the point that identification of Communists with a cause did not make the cause wrong: "Obviously in a democracy the Communists are smart enough from time to tinie to stand for a good thing." He asked: "If the Communist Party says two and two are four, and we know it to be so, shall we oppose it?"13

The point of view of the "joiners," whom the Los Angeles Times wished to censure, was stated by Mrs. March. She and her husband Frederic had appeared before the House Un-American Activities Committee in 1940 and were completely cleared by Martin Dies, its chairman, although advised by Mr. Dies never to "participate in anything in the future without consulting the American Legion or ... [the] local Chamber of Commerce."14

10 BARRETT at 340 .

11 Id. at $211,208,210$.

$12 I d$. at $193-4$.

$13 \mathrm{Id}$. at 201 .

14 Id. at 224. Contemporary newspaper accounts show that testimony of a Mr. Leech given before a Los Angeles Grand Jury imvestigating a murder case had mentioned Frederic March, 
Thinking this "a thin life for an American" they continued to lend their names and energies to what they believed good causes because they believed we cannot "sit back in fear and never espouse anything, and never fight against anything, for fear that some Communist might be on the Board. We can't afford to have them the only people in America who work for common decency." 15

\section{The Committee's Use of Evidence}

The test of "guilt by association" which the conmittee frequently used has often been roundly-and uncritically-denounced. Dubious associates do tend to create an unfavorable presumption. The reputation of a girl often depends on the conpany she keeps. Even judges apply the rule noscitur a sociis in interpreting statutes. Thus an individual's associations seem a proper subject of consideration in determining his communistic tendencies. Insistence that a suspected person be a "card-carrying communist" would be folly. Even Ernest Besig, the director of the northern California branch of the American Civil Liberties Uinon, showed in his testimony that the associations of individuals played a part in determining his judgment concerning the communistic character of an organization. ${ }^{10}$

The real issue is how the test is applied. In statutory construction the rule noscitur a sociis is only one consideration weighed in ascertaining a legislature's intent. Other relevant factors often outweigh it. In the case of an individual an unfavorable impression created by his being seen in bad company may well be offset by an explanation of the circumstances or positive evidence concerning the excellence of his character.

The mistake the Tenney committee made was to consider "guilt by association" an irrebuttable test. If a Communist joined an organization it became subversive. Thus all its members became fellow travellers and membership of one in a different group made still others guilty of "Stalinism"in an ever widening circle. ${ }^{17}$

among other actors, as being "Red." Mr. March accompanied by his actress-wife voluntarily appeared before the Dies committee with other novie stars. Dies was quoted by the New York Times as stating that March and some others "are not, and never have been sympathetic with the Communist movement." Aug. 21, 1940, p. 21, col. 2. The New York Times had previously commented editorially, Aug. 16, p. 14, col. 2:

"It is hard to understand why the Leech testimony in Los Angeles was ever made public. Being made public, it became news of national interest which had to be printed. As a result the persons named ran the danger of impairment of their main property and capital-their standing in the public eye ... What is smister in the present episode is . . the misuse of supposedly correct legal machinery to give irresponsible witnesses a chance to smear reputations."

15 BARRETT at 232.

16 Id. at 267.

17 Id. at 346-52. Barrett points out that "the committee operated on the theory (apparently common to investigative agencies in this field) that Communists and their sympathizers can be detected quite objectively by examining 'documentary evidence' of their associations." The committee claims that the reader examining the reports can "easily arrive at indisputable conclusions susceptible to the most thorough documentation and proof."

Such documentation, however, consists of noting that the individual protested against the conduct of the Dies counmittee or the Tenney committee, that he was mentioned favorably in the People's Daily World, that he signed a petition in favor of a known Communist or that he belonged to or spoke before certain organizations found to be communist fronts. That such conservatives as Senator MicKellar were also present at the proscribed meetings or that the 
Once the presence of a "Stalinist" was established other evidence became immaterial. The committee condemned the Writers' Congress at UCLA because it objected to some of the participants. It did not examine the printed record of the Congress' proceedings to discover what, if any, subversive acts took place; it ignored the fact that the President of the United States and Wendell Willkie both sent congratulatory telegrams to the Congress. ${ }^{18}$ Likewise in the case of workers' schools the Tenney committee paid no attention to testimony of faculty members of the University of California who had served on the schools' boards of directors with labor leaders that they had detected no subversive conduct, or to minutes showing a struggle to maintain an even balance between the $A F$ of $L$ and the CIO in the schools' activities. The committee had found "Stalinists" present. It did not wish to inquire "how nnuch poison does it take to make a cup of coffee harmful?"19

The time honored pledge exacted of witnesses calls upon them to tell not only the truth but the "whole truth." Such a requirement becomes doubly important while investigating subversives. The rapid shift in scene from wartime cooperation with Russia to the present hostility forces a close inquiry into dates and circumstances. Acts which were entirely innocent yestesday may be properly suspect if done today.

One count in the indictment set forth June 24th, 1949, in the Senate Daily Journal against Frederic March, the actor, is that he had been a "Sponsor, with known Communists, of Congress of American-Soviet Friendship, a C.P. front." Reference to the 1948 report as cited shows the following entry: ${ }^{20}$

Among the sponsors to the 1942 Congress of American-Soviet Friendship were the following: C. A. Dykstra, Philip Murray, Sidney Hillman, Harry Bridges, Joseph Curran, Reid Robinson, A. F. Whitney, Charles Claplin, Jo Davidson, Albert Kahn, Serge Koussevitsky, Frederic March, Raymond Massey, Mary McLeod Bethune, Rev. A. Clayton Powell, Jr., Albert Einstein, William Rose Benet, Van Wyck Brooks, Pearl Buck, Thomas Mann, Eugene O'Neill and Franz Werfel.

suspect had other associations are facts treated as irrelevant or more camouflage. So is testimony explaining the reasons for their acts of such witnesses as Judge Yankwich, Emmet Lavery and Mrs. March. The committee concentrates upon its card file system of entries which in its eyes provides "the Communist fever chart of an individual or an organization."

The case of Frederic and Florence March demonstrates the fallacy of such "proof." Although they belonged to 10 organizations blacklisted by Tenney they contributed from 1935 through 1948 a total of $\$ 57,324.06$ to some 250 organizations only a small fraction of which, according to Professor Barrett, "have political implications." During the Nazi-Soviet pact they showed clearly that they were not fellow-travelers. They appeared on Broadway in "The American Way," a play attacking the German-American Bund, they contributed toward sending an ambulance to Finland and were guests of the Finish minister at the opening in Washing of the anti-Russian play "There Shall Be No Night." Id. at 388-90.

18 Id. at 122-45, especially at 124, 131. President Sproul of the University of Califormia spoke at the first meeting "in response to a direct personal request from the President of the United States." California Monthly, 40-B (June 1951).

19 BarReTt at 109-11, 120-1.

20 Id. at 385; Fourth Report of the Senate Fact-Findang ComantTtee on Un-AareriCAN ACTIVITIES; CoMarunist Front Organizations 324 (1948). (Emphasis added.) 
The entry fails to add that other sponsors included Secretary and Mrs. Cordell Hull, Lord and Lady Halifax, Mr. and Mrs. E. R. Stettinius, Jr., Secretary and Mrs. Jesse Jones, and Senator Kenneth McKellar. ${ }^{21}$

Mrs. Frederic March was also censured for having been a delegate to the First International Congress of Women called in Paris in 1945. The American delegation had been invited by Henri Bonnet, French ambassador to the United States, had been wished Godspeed by Mrs. Roosevelt, had resided in Paris in a hotel under the jurisdiction of the United States Army, had its head entertained by the American Ambassador at the Embassy, and had received sympathetic coverage in the New York Times, the Tribune, and Vogue.22

The Tenney committee declared that Mrs. March (among others) had never "challenged, demed or attempted to refute a single fact" in its indictment of her. ${ }^{23}$ The statement may be true in a narrow technical sense, but it ignores the demurrer which Mrs. March entered against the committee's charges. She testified under oath before the committee that she was not, never had been and did not intend to become a Communist, nor had she ever knowingly joined an organization that was communist controlled or communist dominated and that all goals at the Paris Congress were carefully stated to be sought "under the existing governments and according to the laws of each country." She explained her reasons for going to the Paris Congress: ${ }^{24}$

I wasn't fooled into going to the Congress in Europe. When examined in the light of the feeling in our country today, we may see it differently, than we did at that time. I have with me the coverage in the New York Times, the coverage in Vogue Magazine and the coverage in the New Yorker. This was right after the war, if you will remember, and it was a time when we had worked as allies with Russia. We were emotional about their defense at Stalingrad and the meeting of our armies in Europe. It was a time when those women in Europe were real heroines in their countries because of what they did in the Resistance. None of us thought we were doing an evil thing to meet with these women and try to find a way for a lasting peace and to feed the children made homeless by the war. I wasn't fooled into going. I went because $I$ thought that was the way human beings would behave in the future.

Despite a feeling of disgrace at being treated as a culprit, Mrs. March refused in 1948 to denounce the Congress she had attended or to confess guilt for having associated with a known French Communnist in 1945. As she told Senator Tenney: ${ }^{25}$

If you meet a woman and see her name branded on her arm because she has been in a concentration camp, and you know that her husband was

21 Barretr at 385. The N.Y.Times, Nov. 8, 1942, p. 36, col. 4, discloses that General Eisenhower sent a message of greetings to the Congress.

22 BARRETT at 221-2.

23 Fifth Report of the Senjate Fact-Finding Comanttee on Un-Amatrican Activities 689-90 (1949).

24 BARRETT at 213, 219, 231, 225-6.

25 Id. at $222,230$. 
killed by the Nazis, and that woman is out talking about how to feed the children who were maimed, and how to feed the children who were orphaned, I find it very hard as a woman to draw away from her because I don't agree with her political ideology ... That was a great opportunity at the time for the people of the world to get together. I felt this was one of the most rewarding experiences in my life ... It was a wonderful thing to see women come from forty-two countries and cut through the barriers of difference in political thinking, differences in color, differences in religion, differences in language, and sit down together like neighbors and ask, "How shall we feed the children who are starving because of war," and "How shall we heal the hittle crippled children, how shall we establish orphan asylums ... ?"

The difficult task of detecting real subversives and warning others against them requires a breadth of sound knowledge and a clear understanding of the issues at stake. We find that in 1943 Tenney sought to force delegates to national party conventions to pledge support to "Jeffersonian Democracy" or the "Republicanism of Abraham Lincoln" as the case might be. ${ }^{26}$ In 1948 the Tenney committee sought to keep federal funds from schools whose faculty helped advocate anything "contrary to Aunerican principles of democracy."27 Yet that same year when lecturing a witness about the differences between a republic and a democracy Senator Tenney declared: "Under a deinocratic society the major party can vote the minority party out of power. They can put them into slavery or take them out and shoot them."

Much depends upon the keenness of an investigator's insight into what is relevant to the inquiry and what evidence has probative force. In the Zoot-Suit riots in Los Angeles the Tenney committee found a "devilish pattern woven by revolutionary Marxists . . . Marxian dialectic applied with Machiavelian [sic] subtleties." It found that some Communists had rushed to the aid of the Mexican-American youths who were accused of murder. Others who joined in the youths' defense were blacklisted as sponsors of a subversive organization, without any, note being made of why they might reasonably have believed that they were merely following the American tradition of extending justice to all. As far as the Tenney committee was concerned it was irrelevant that a committee appointed by Governor Warren had reported most of the trouble in Los Angeles arose from inadequate living conditions, inflammatory newspaper reports and unsound police practices, and that the Califorina District Court of Appeal reversed the conviction of the Mexican-American youths, who had been condemned as murderers, and criticized the conduct of their trial. ${ }^{29}$

26 Id. at 298, quoting S. B. No. 1017 (1943), which even after being radically amended failed to pass in the Senate.

27 BARRETT at 302, quoting S. B. No. 1181 (1947). The bill failed to get out of a Senate committee.

2S BARRETT at 215. Tenney was speaking to Mrs. March who was on the stand and who had confessed being "a long time Jeffersonian Democrat."

29 Id. at 89-104, 341. Senator Tenney promised to but never did include in a subsequent report mention of the appellate decision (People v. Zammora, $66 \mathrm{Cal}$. App. 2d 166, 152 P.2d 180 (1944), a unanimous decision). 
On the other hand, little was immaterial when the Tenney committee was demonstrating subversive tendencies in Marin County. It duly recorded evidence against a suspect in Fairfax, a Marin County town of 3,000 population. She and others had told a witness that it would be "carrying things just a little bit too far" to open meetings of the local taxpayers association with a pledge of allegiance to the flag, the playing of the national anthem, and a short prayer..$^{30}$

\section{Results Achieved by the Committee}

The first point to note is the failure of the committee to surround its activities with the safeguards normally provided in court to eliminate erroneous decisions. In fact, the committee rejoiced that it did not have to provide the ordinary procedures observed in a court of law. It said: ${ }^{31}$

The committee, empowered to subpoena witnesses and to examine them under oath, not being bound by the rules of evidence and armed with the power to punish for contempt through the initiation of proper criminal proceedings, and for perjury in the event that crime might be established, cuts through the technical restriction of other investigative units which are primarily law-enforcing in character rather than fact-finding.

The legislative successes of the committee and its members were minor. They procured legislation requiring organizations which sought to overthrow the government by force to register, barred anyone with these objectives from employment in any state department or as teachers, and denied them the use of public school buildings. Persons guilty of contempt before a legislative committee were not to be employed by the state, nor were licenses to be granted foreign language schools where the instruction materially tended to create disloyalty. United States history courses were to be prerequisite to advanced courses and restrictions were placed upon use of the name of the University of California. ${ }^{32}$

The committee failed to procure passage of the elaborate Anti-Communist Code it proposed in 1949. This gave employers producing goods for national defense the right to discharge any person reasonably suspected of advocating commumsm and permitted labor unions to deny membership to him. Teachers who sought to inculcate upon any school property of the state "a preference in a pupil's mind for any plan of government except the American plan" were to be guilty of a misdemeanor. Written records open to public inspection were to be kept at closed meetings in which communism was advocated and buildings in which subversive organizations held meetings were to be abated as public nuisances. Also a defimition of communism embraced anyone who "knowingly and voluntarily assembles with a group of persons at which place Communism is advocated." Special loyalty oaths

30 BARRETT at 186-7.

31 Id. at 27-8, quoting Report Jonnt Fact-Finding Committee, on Un-American ACtivities in CaITfornia to CaITFORNIA Legislature 8 (1943).

32 BARRETT at 296-302. As recently as January 1948 no organization had registered under the Subversive Organizations Registration Act passed in 1941. The act denying the use of public school buildings was declared unconstitutional. Danskin v. San Diego Unified Sch. Dist., 28 Cal. 2d 536, 171 P.2d 885 (1946). 
were sought from candidates for public office, all state employees and members of the state bar. Constitutional amendments were proposed prescribing such oaths for all legislators and public employees and giving the legislature rather than the Regents power to insure the loyalty of the officers and employees of the University of California. ${ }^{33}$

The committee did not provide a list of communist front organizations which the loyal citizen might read with confidence. Only one out of every five of the groups cited appeared in the U.S. Attorney General's enumeration of suspect organizations. ${ }^{34}$ Also, too many individuals as well as too many groups were condemned. Scarcely anyone could read the Tenney indictments without finding the name of one or more persons for whose loyalty he could personally vouch. Newspaper editorials, church groups and the League of Women Voters expressed their lack of confidence. ${ }^{35}$

Voters in Fairfax and in Richmond ignored the committee's comments concerning candidates whom it suspected. ${ }^{36}$ Finally the legislature itself turned against Tenney when he openly approved the listing with several openly avowed Commumists of various prominent Democrats, including six assemblymen, two state senators, two congressmen, the state chairman, and a national committeeman. It continued the committee only with the understanding that Tenney would not be a member. ${ }^{37}$

The extent to which intimidation by the committee succeeded in compelling adherence to its standards is difficult to measure, but the committee made liberal use of the threat of investigation and exposure much like the threat of criminal prosecution. Organizations were warned against listening to allegedly subversive individuals. A county assessor was officially requested to remove the tax exemption of a church. University presidents were warned that prospective faculty members had allegedly subversive affiliations. The state bar was called upon to investigate the "conduct of those attorneys who consistently represent persons and organizations suspected of un-American activities." 38

A barrage of publicity in the Alert, the editor of which wrote the 1949 report for the committee, accused anyone opposed to the committee's legislative program, "be he Communist, fellow traveller or yellow traveller," of

33 BARRETT at 302-6.

34 Compare Barrett's Tenney committee list, 355-360, with latest Consolidated Iist put out by the U.S. Attorney General, Sept. 5, 1950. The Attorney General's list sliould not be confused with the Guide to Subversive Organizations and Publications (and Appendix) Revised, May 14, 1951, 82d Cong., 1st Sess., House Doc. No. 137, prepared and released by the House of Representative's Committee on Un-American Activities now under Congressman Wood of Georgia. The appendix of the latter contains a copy of the latest Attorney General's list.

35 BARReTr at 280-95, 307, 315-9. The Presbyterian Synod adopted a report of its Social Education and Action Committee denouncing the Tenney committee as a "smear group": "We believe that this Committee has done a service in publicizing the activities of professional communists, but its methods liave so discredited it as to cast suspicion on its findings, create confusion in the minds of the people and, injure the reputation of perfectly loyal citizens by improper inference." Open Forum, July 24, 1948. This report ends with the request for the legishature "to replace Senator Tenney and his committee with more judicial-minded men who will preserve democratic processes." Quoted in BARRETT at 315-17.

$361 d$, at $182,191$.

37 Id. at $321-3$.

38 Id, at $342-3$. 
being "as dangerously un-American as the openly-avowed Red traitors." 30 The effect of such techniques was explained to the California League of Women Voters by an unnained California senator: ${ }^{40}$

One hesitates to express his honest convictions in a public forum because of the danger of being misunderstood and forever labeled as being a "Fellow-traveler", leftist, disloyal, or some other derogatory term, which may prejudice people against him and seriously handicap his future usefulness.

The harm which might be done to individuals by unwarranted attacks is more easily measured. For example, Judge Leon R. Yankwich gave a lecture before the Peoples Educational Center in 1945 on "Racialism as Dogma," which was first prepared for the Newman Club. After he defended before the committee his belief that he was right in delivering such a lecture before any club, "on my own terms," the committee found that "Judge Yankwich's conduct and attitude is a disgrace upon the Federal Bench ... no condemnation is strong enough to characterize such action ... a man such as Yankwich is not qualified, because of his obvious bias and sympathy for pro-Communists, pro-Soviet causes to sit on the Federal Bench." The newspapers of California rallied to Yankwich's defense. They declared that he is "an honorable judge, a staunch American and an eminent humamitarian," that "he literally lives and breathes Americanism," that "for a man of Judge Yankwich's standing to deny a lecture along stout American lines to any group is comparable to a minister withholding the Gospel because the seeker may be an unbeliever," and that the Tenney committee had been "guilty of a most vicious piece of character assassination under the guise of investigating un-American activities."

Nonetheless the Tenney committee material appeared in Counterattack, an East Coast publication which called upon Congress to conduct an inquiry into the activities of Judge Yankwich, and the Counterattack article in turn was quoted in an issue of the Tablet, a Catholic newspaper in Brooklyn, New York. ${ }^{41}$

The Institute for Democratic Education, Inc., a non-profit charitable organization, sponsored by the Anti-Defamation League of B'nai Brith for the purpose of counteracting prejudice and discrimination and improving human relations in the United States was attacked in 1947 in an anonymous letter. The 1948 report of the Tenney committee charged it with being a. communist front organization on the basis of a "report in the files of the Committee" which as set forth proved to be (although not labeled as such) an almost verbatim copy of the 1947 anonymous letter. The president of the Institute, Rabbi Rosenblum, protested in August, 1948, and Senator Tenney replied in December that,

continuing investigation ... reveals that ... [the Institute is] sponsored by responsible individuals and groups of unquestioned loyalty. The programs $\ldots$ are in full keeping with the best American traditions and ideals and it

\footnotetext{
39 BARRETT at 308, 320, 322. Edward Gibbons, the editor, also wrote a portion of the 1948 report. Id. at 67 .

$40 \mathrm{Id}$. at 315 .

41 Id. at $237,245-6,248-51,252-5,256$.
} 
is the design of the sponsoring individuals and groups to inculcate and preserve in the hearts and conscience of the American people love and loyalty for and to our country and the great principles of American liberty and democracy.

He confessed that Harold Franklin, the program director, had been listed as a Communist because of confusion with another Harold Franklin.

The House Un-American Activities Committee listed the Institute as a communist front in its publication Citations on December 18, 1948. After the Institute protested, Congressman Wood regretted the citation and stated that the committee had,

informed various agencies of the Armed Services, the American Legion and the Federal Bureau of Investigation, that the citation ... had been withdrawn. The Government Printing Office which was distributing the citation booklet was notified that the names . . . should be deleted from future reprints of the booklet. The Committee has also attempted to secure a list of the individuals and organizations to whom copies of the citation booklet were sold by the Government Printing Office. A copy of Senator Tenney's letter to Mr. Robinson was immediately placed in all copies of the citation booklet by the Committee, which had not been distributed to the public.

Meanwhile, the chairman of the Committee on Education of the Conference of Anjerican Small Business Organizations of Chicago, Illinois, had written to Ohio State University "requesting an explanation of an award which the University had nade to the Institute for Denocratic Education, calling attention to the 1948 Tenney committee report." After almost four months of correspondence, Mr. George D. Hawkins wrote the president of the Institute a letter of retraction ending, "It certainly is unfortunate for any committee to publicize before their facts are indisputable." 42

\section{Questions to Consider}

The foregoing does not summarize all that is in Professor Barrett's book nor does it tell the full story of the Tenney committee. Yet it enables us to consider the issue whether the committee followed practices which should be corrected. In procuring a reversal in appellate practice one does not need to establish that the trial judge erred in all respects or even in most. It is sufficient to show material prejudicial error. Thus without attempting to review all the work of the Tenney committee there seems to be sufficient reason for us to consider the basic question whether legislative committees investigating subversive activities help to maintain or tend to impair our institutions.

The following pages will attempt to raise the questions as the writer sees them. Different persons may find different answers but all loyal and intelligent citizens should at least face the issues.

The American heritage has been one of personal freedom. While we strive to promote the general welfare we also seek to preserve the individual's rights. In fact we believe that the general good is best served in the

12 Id. at $269,270,273,273-4,274-5,275-6,276,279$. 
economic sphere by private enterprise and in the political by freedom of thought and expression, the right freely to assemble and to petition for the redress of grievances. "He governs best who governs least."

Totalitarian governments speak of duties, not of rights. The individual exists for the benefit of the state. The state has no hesitancy in controlling thought and restraining freedom of expression; individuals who do not conform to the party line must face the consequences. Informers are encouraged to relate gossip and report their suspicions, children to spy on their parents and workers on their fellows. Only one party exists. Non-conformists are capitalistic saboteurs; they cannot teach, preach or even earn a livelihood.

Is there a Gresham's law applying to civil liberties? Do authoritarian threats inexorably drive out libertarian policies as bad money drives out good?

There appears to be a growing contempt for the rights of the individual and a casual attitude toward our traditional freedoms. Note J. Parnell Thomas' statement to a witness before the House Un-American Activities Committee that the only rights which the witness has are those given him by the committee. ${ }^{43}$ Recently Chief Justice Vinson in one of his opinions stressed the point that the anti-communist oath "touches only a relative handful of persons, leaving the great majority ... completely free from restraint." ${ }^{44} \mathrm{~A}$ writer of science fiction, which in the physical world sometimes presages those things to come, has one of his characters remarking that in the war with Arcturus the Arcturians were so horrible that it was better for a thousand innocent persons to be shot on sight as spies than for one Arcturian to escape. ${ }^{45}$

If the problems of survival do not inevitably force us to adopt our opponents' tactics-to fight fire with fire-the issue changes. The question becomes, "is our situation so desperate that we must sacrifice many of our liberties to preserve the remainder?"

Comparisons help maintain perspective. Looking back into our history we find that adherence to the Bill of Rights did not prove disastrous even in periods of great peril. During the War of $1812 \mathrm{New}$ Englanders openly discussed secession; the British blockaded our ports, invaded our soil and burned the national capitol. From 1861 to 1865 we engaged in a great civil war testing whether a nation dedicated to liberty "could long endure."

Today our way of life faces threats from fanatical supporters of a hostile ideology. But today the United States produces more of many of the essentials of war, such as steel, than all the rest of the world combined. It no longer has a monopoly of the atomic bomb, but, we are told, it has a great superiority. Unfortunately it disbanded its army after World War II and neglected to retain air suprenacy, but it still maintains unchallenged command of the seas. While it is rebuilding its army and air force the ramparts

43 Carr, Un-American Activities Committe, 18 U. OF CHr. L. REV. 619 (1951).

11 American Communications Assn. v. Douds, 339 U.S. 382, 404, quoted by McCloskcy, Free Speeck, Sedition and the Constitution, 45 Axrer. Por. Sar. REv. 670 (1951).

15 Browt, What Mad UNIVERSE 137. 
it watches are in Germany, Iceland, Greenland, Okinawa, Formosa, and Korea, thousands of miles of ocean removed from its borders.

There is also the internal threat from subversives. J. Edgar Hoover declared in March of this year that the Communist Party had 43,217 members. The Party boasts that for every member "there are ten others willing and able to do the party's work." Even so the total is less than 500,000 out of a population of more than $150,000,000 .{ }^{46}$ Compare the situation during the present cold war with earlier eras in our history. During the War of 1812 at least five states out of eighteen did not want to fight. During World War I there were more than 3,500,000 native born Germans, Austrians and Turks in the country to say nothing of hyphenated Americans of similar alien parentage. Before our entry into World War II there was estimated to be at least 800 pro-fascist or pro-Nazi organizations in the United States. At the time of Pearl Harbor the Japanese in Hawaii constituted fully onethird of the population. ${ }^{47}$

The considerations, of course, do not warrant any conclusion that we should become complacent about the totalitarian threat today. Like cancer it cannot be ignored even in its early stages. The historical perspective, however, suggests that there is no immediate need to become hysterical about the situation-even assuming that hysteria ever helps. There is time for us to do some careful thinking. In fact, that is imperative. The best hope to cure the communist threat, like that of cancer, is to avoid quack treatments and to determine carefully the efficacy of the cure proposed for the disease. There is scant comfort in knowing that the operation was a success if the patient dies.

One query is, does the Tenney technique achieve its purpose of eliminating subversives and protecting our institutions? Senator Tenney believes that the public's wrath should be heaped upon those who have strayed from the footsteps of the Founding Fathers. Arguing by analogy some wonder whether outbursts of parental anger provide the best way of guiding a possibly wayward child. In opposing the committee's 1949 program, Assemblyman Yorty, long a friend and supporter of Tenney and himself chairman of the predecessor of the Un-American Activities Committee, expressed the view that "young people should be given the opportunity to outgrow youthful ventures into questionable programs without being permanently branded as Communists," and expressed fear that the affidavits required by the bills might make permanent Communists of temporarily misled dupes and fellow travelers: ${ }^{48}$

It seems probable that if such persons are once forced to sign an affidavit disclosing their affiliation with such organizations and thereby bringing their loyalty into question, they will have become part of a suspected group, they will feel a kinship with other suspected persons, and this will render them more susceptible to Communist propaganda and tactics.

46 Contmunist Threat in U.S. An Interview with J. Edgar Hoover, 30 U. S. NEWs \& WORLD REPORT 32-37 (March, 1951).

47 Lee, Subversive Individuals of Minority Status, 223 ANnars 164 (1942). Statistical Abstract of the United States 1947, 40, 59.

46 BARRETT at 313 . 
Equally important is the question, does the Tenney technique "ferret out the dangerous Communists, the real spies, traitors and saboteurs?" Indiscriminate accusations of persons whose names have been copied from lists nerely nuddy the water. The really dangerous agents lie low. Their names do not appear as sponsors of questionable organizations nor are they to be seen associating with fellow travelers. Is there not merit in the observation of Assemblyman Yorty that: ${ }^{40}$

Sweeping general charges by investigating committees, which smear loyal Americans, are to be condemned as not only a wrong against the citizens unjustifiably branded as Communists, but also because of the fact that when an innocent person is charged with being a Communist, the Communist Party is benefited by being better able to cover its real members.

Does not the blunderbuss technique do positive harm? Sensational charges brought agamst persons in prominent positions tend to breed fear and suspicion among loyal citizens-an end sought by all saboteurs. When subsequently we learn that the charges are ill-considered, if not altogether unfounded, does it not impair confidence in our government since one of its agencies played us false?

Will not the intimidation which results from activities such as those of Temiey endanger our right to differ with constituted authority and hit "homespun American radicals," as apart from subversives who take orders from Moscow? The Califorma League of Women Voters feared that the result would be "to suppress the expression of any currently unpopular point of view and to curtail the freedom of speech and assembly upon which this democracy is based." 50

Does not effective action in a country as large as the United States require association? Suppose one-half of the openly avowed, or easily detected, Communists espouse every good cause and rush in to right all wrongs. Must every loyal American refuse to act because the Communists support the same measure? If so, the concealed saboteurs can stir up bitterness and resentment among those with justified grievances. Will they not find it easier to drive the aggrieved into the communist camp?

When Senator Tenney investigated the Peoples Education Center, an attenipt of laboring groups to found workers' schools along lines which had been successful in England, one of the university professors who was attenipting to help combat the Communists in the Center warned him in 1946 that "the net effect of an investigation like this is to make people like ine get off the Board." $5 x$ Despite Tenney's condemnation, Emmet Lavery remained in the Screen Writers Guild; he fought the Communists' attempt to dominate. When the Attorney General of the United States prepared his list of suspect organizations he included the PEC, but not the Guild. Whose tactics acconiplished most for Americanism-those of Tenney or those of Lavery?

49 BARRETT at 324.

$50 I d$. at $30 \%$, quoting a letter sent to the California legislators regarding loyalty oaths, April 7, 1949.

51 Id. at 121 . 
All of which leads up to the question: are legislative mvestigating committees the most effective device for dealing with subversives? Although there have been good committees, such as the one which helped catapult Mr. Truman to the presidency, they have long been the subject of criticism. An observer of the Seventeenth Congress remarked, "Committees pointed out little items, peeped behind curtains and under beds, not so eager, it would appear, to correct abuses as to collect campaign material for damaging some candidate." 52 Dean Wigmore, the great authority on evidence, felt outraged by the congressional investigations of the 1920's. He said: ${ }^{53}$

The Senatorial debauch of investigations ... poking into political garbage cans and dragging the sewers of political intrigue ... filled the winter ... with a stencl which has not yet passed away. Instead of employing the constitutional, manly, fair procedure of impeachment, the Senate flung self-respect and fairness to the winds. As a prosecutor, the Senate presented a spectacle [and] fell ... in popular estimate to the level of professional searchers of the inunicipal dunghills ...

May not the trouble be that legislators are not trained as judges; that they suffer from a natural tendency, for which the San Francisco Chronicle criticised the Dies, Thomas and Tenney committees, "of grabbing headlimes first and then looking to see if there is available evidence to support them." 54

\section{Remedies}

It does not suffice to show that something is amiss. There remains to discuss what can be done about it. Many possibilities exist. ${ }^{55}$

One possible course is to appeal to the courts, but the probabilities of gaining protection for constitutional rights asserted against legislative committees are not great. As the Supreme Court poimted out im the case of McGrain v. Daugherty, involving a congressional investigation, "the power of inquiry - with the process to enforce it - is an essential and appropriate auxiliary to the legislative function ... that this power, if sustained, may be abusively and oppressively exerted . . . affords no ground for denying the power. The same contention might be directed against the power to legislate, and of course would be unavailing." "56

Justice Van Devanter, speaking for the Court, did not foreclose all doors to relief. He noted that if "controlling limitations of restrictions are disregarded" the decisions in Kilbourn v. Thompson and Marshall v. Gordon "point to admissible ineasures of relief." "5T"

52 Ives, In Place of Congressional "Circuses," N.Y. Times Magazine, p. 20, Aug. 27, 1950.

53 Gilligan, Congressional Investigations, 41 J. CRTM. L. \& CRTMnorogY 618 (1951), quoting from Wigmore, Legislative Power to Compel Testimonial Disclosure, 19 Inx. L. Rev. 452, 453 (1925).

54 BARRETT at 327, quoting an editorial, June 22, 1949.

55 The Spring 1951 issue of the Chicago Law Review is devoted to a symposium on Congressional Investigations. Thanks are due it for inuch that follows. See also references supra note 2 .

56 McGrain v. Daugherty, 273 U.S. 135, 174, 175 (1927).

57 In Marshall v. Gordon, 243 U.S. 521 (1917), the Court bad refused to sustain a conviction for contempt of a person who had merely published and sent to one of the House 
In practice this protection is more theoretical than real. The opinion of Justice Holtzoff in United States v. Bryan illustrates the point. He stated that a legislative committee might make inquiries: ${ }^{58}$

If the subject under scrutiny may have any possible relevancy and materiality, no matter how remote, to some possible legislation ... Moreover, the relevancy and materiality of the subject matter must be presumed. The burden is on one who maintains the contrary to establish his contention.

Since the courts "seein to be increasingly unwilling either to refuse to sustain a committee's actions or to interfere with inquiries in any way" the practical view of the matter was expressed by a majority of the United States Court of Appeals of the District of Columbia in the case of Barsky v. United States: ${ }^{60}$

The remedy for unseemly conduct, if any, by Committees of Congress is for Congress, or for the people ... The courts have no authority to speak or act upon the conduct by the legislative branch of its own business, so long as the bounds of power and pertinency are not exceeded.

Involving, as it does, the Tenney committee itself, the decision of the Supreme Court in Tenney v. Brandhove is of special interest. ${ }^{\text {.1 }}$ Brandhove had circulated a petition against further funds for the Tenney committee charging that the committee had used him as a tool in order to smear as a "Red" a candidate for the post of mayor in San Francisco and that others had conspired with the Tenney committee to this end. The committee summoned Brandhove to appear before it on January 29th. He refused to testify and was prosecuted for contempt in the state courts, but the jury failed to return a verdict and the prosecution was dropped. After Brandhove's refusal to testify Senator Tenney read into the record derogatory statements concerning Brandhove including one concerning his alleged criminal record. Brandhove sued the members of the committee under a Reconstruction Act against persons depriving citizens of constitutional rights. ${ }^{02}$ Brandhove alleged that the January 29 hearing "was not held for a legislative purpose" but "to intimidate and silence" him. The district judge dismissed the action, but was reversed by the court of appeals. The Supreme Court reversed, affirming the district court action.

Justice Douglas, dissenting, declared that "It is one thing to give great leeway to the legislative right of speech, debate, and investigation. But

committee chairmen a letter derogatory of the committee and its purposes. The letter, while "irritating," was not calculated or likely to affect the House in any of its functions. In Kilbourn v. Thompson, 103 U.S. 168 (1880), according to Justice Van Devanter, the Court had ruled that "neither house is invested with general power to inquire into private affairs and compel disclosures" and as a necessary deduction therefrom "a witness rightfully may refuse to answer where the bounds of the power are exceeded or the questions are not pertinent to the matter under inquiry." See McGrain v. Daugherty, supra note 56 at 176.

5872 F. Supp. 58, 61 (D. C. 1947). (Emphasis added.)

59 McGeary, Congressional Investigations; Historical Developnent, 18 U. oF CHr. L. REv. 425,434 (1951).

60167 F.2d 241, 250 (D. C. Cir. 1948), cert. denied, 334 U.S. 843 (1948).

01341 U. S. 367 (1951). BARRETT at $42-4,44 n$.

6217 STAT. 13, $\$ \$ 1,2$ (1871), now in 8 U.S.C. $\$ 47(3)$ (1946). 
when a committee perverts its power, brings down on an individual the whole weight of government for an illegal or corrupt purpose, the reason for the immunity ends." He stated:

It is speech and debate in the legislative department which our constitutional scheme makes privileged. Included, of course, are the actions of legislative committees that are authorized to conduct hearings or make investigations so as to lay the foundation for legislative action. But we are apparently holding today that the actions of those committees have no limits in the eyes of the law. May they depart with impunity from their legislative functions, sit as kangaroo courts, and try men for their loyalty and their political beliefs? May they substitute trial before juries? May they sit as a board of censors over imdustry, prepare their blacklists of citizens, and issue pronouncements as devastating as any bill of attainder? No other public official has complete immunity for his actions. ${ }^{63}$

Justice Black concurred with the Court's holding that the Civil Rights statutes "were not intended to nuake legislators personally liable for damages to a witness injured by a committee exercising legislative power." $\mathrm{He}$ went on, however, to express his opimion that the Supreine Court's decision that the niembers of the Tenney committee could not be sued "is not a holding that their alleged persecution of Brandhove is legal conduct ... there is still much room for challenge to the Committee action . . . ." Justice Black thought that Brandhove would be able to defend himself against a contempt proceeding "on the ground that the resolution creating the Committee or the Committee's actions under it were unconstitutional and void." He stated:

In this connection it is not out of place to observe that the resolution creating the Committee is so broadly drawn that grave doubts are raised as to whether the Committee could constitutionally exercise all the powers purportedly bestowed on it. In part, the resolution directs the Committee "to ascertain ... all facts relating to the activities of persons and groups known or suspected to be dominated or controlled by a foreign power, and who owe allegiance thereto because of religious, racial, political, ideological, philosophical, or other ties, including but not limited to the influence upon all such persons and groups of education, economic circumstances, social positions, fraternal and casual associations, living standards, race, religion, political, ancestry and the activities of paid provocation ... " Cal. Senate Resolution 75, June 20,1947. Of course the Court does not in any way sanction a legislative inquisition of the type apparently authorized by this resolution. ${ }^{64}$

It was, however, Justice Frankfurter who expressed the nujority opinion. He stated "The privilege of legislators to be free from arrest or civil process for what they do or say in legislative proceedings has tap roots in the Parliamentary struggles of the Sixteenth and Seventeenth Centuries." He reaffirmed the power of the Court to sustain the rights of private individuals when it found that legislatures sought unwarrantedly to extend their

03 Tenney v. Brandhove, supra note 61 at 381-383.

64 Id. at 379,380 . 
role. But in this case he noted that Brandhove had indicated "that evidence previously given by him to the committee was false, and he raised serious charges concerning the work of a committee investigating a problem within legislative concern." Thus the committee was entitled to examine him."5

As to the relationship in general between courts and the legislature, Justice Frankfurter said:

The claim of an unworthy purpose does not destroy the privilege. Legislators are immune from deterrents to the uninhibited discharge of their legislative duty, not for their private indulgence but for the public good. One must not expect uncommon courage even in legislators. The privilege would be of little value if they could be subjected to the cost and inconvenience and distractions of a trial upon a conclusion of the pleader, or to the hazard of a judgment against them based upon a jury's speculation as to motives ... Investigations, whether by standing or special committees, are an established part of representative government. Legislative committees have been charged with losing sight of their duty of disinterestedness. In times of political passion, dishonest or vindictive motives are readily attributed to legislative conduct and as readily believed. Courts are not the place for such controversies. Self-discipline and the voters must be the ultimate reliance for discouraging or correcting such abuses. ${ }^{06}$

Resort to the polls affords no immediate solution of the problem. Of course the public should select the best possible legislators but in California, at least, the public's unwillingness to pay them more than a mere pittance stands in the way. In any event the quality of representatives depends upon each electoral district. New York may elect a Marcantonio and Wisconsin a McCarthy. Whatever the rest of the country may think about the merits of each it must wait until the voters in that clistrict change their minds.

The remedy attempted in the case of the California Un-American Activities Committee of simply changing the chairman did not suffice. The 1951 report of the Burns committee written by its counsel, Richard E. Combs, contains the same half truths, innuendoes and nonsequiturs of its predecessors.

The University of California was blamed because of inadequate security precautions at the atomic bomb project at the University, despite the fact that the University had no authority in the matter, the security measures in connection with the project being completely under the control of the United States Arny and other agencies of the federal government. ${ }^{07}$

The report solemnly states: "It is a well-known fact that in Soviet embassies and consulates a gardener or chauffeur is usually the real boss and issues orders to the anibassador or the consul." 18 The committee made headlines by reference to a prominent physicist who has generally been conceded much of the credit for having produced the atomic bomb. It is well known that although he once was interested in radical organizations

65 Tenney v. Brandhove, supra note 61 at 372 .

$66 I d$, at 377,378 .

67 California Monthly 40B-40C (June 1951).

68 Sixth Report of the Senate Fact-Finding Conantere on Un-Amarican ActiviTIEs 81 (1951). (Emphasis added.) 
his loyalty has repeatedly been cleared by federal agencies. Nonetheless the committee made much of a report that some alleged Communists sought to procure data from him and ended that section of its report with the punch line: "They knew his record much better than our security agencies, and they evaluated him as a potential traitor." 69

Most of the reforms proposed have been procedural. Changes recommended include larger and better staffs for committees, clearer delineation of the work attempted, granting witnesses the right to consult counsel, to make statements of their own beliefs, to cross-examine adverse witnesses, and granting persons referred to by witnesses the right to appear and to have stenographic copies of the proceedings concerning them. Such suggestions should improve conditions, but they cannot make a bad committee good. They do not go to the heart of the matter. ${ }^{70}$

The essential vice in the actions of many legislative investigating committees is that they depart from the legislative function. Witnesses should be called to provide factual data for legislative purposes. They should not be called before the committee to be tried "in the court of public opimion" and condemned by "pitiless publicity." 11 That the Framers of the Constitution never intended legislatures to act as criminal tribunals clearly appears in the constitutional prohibition against bills of attainder. Legislatures, or their committees, acting as prosecutor, judge and jury do not provide the evenhanded impartial justice to which our heritage entitles us. Congress itself recognizes the undesirability of combining these functions in the rules it has prescribed for the administrative agencies. ${ }^{i 2}$

Publicity, the meat and drink of the politician, is the root of the evil. The more honorable legislators will not seek to raise their fortunes by hearsay, gossip and innuendo directed at a defenseless victim. The less scrupulous do not refrain from sensationalism. They should be removed from temptation.

One proposal is that investigations should be entrusted to special investigating commissions. The British Tribunals of Inquiry, the Moreland Commissioners in New York and the Wickersham, TNEC and the Hoover Commissions in the federal government have been cited as possible models. Senators Thomas and Ives went so far as to propose a bill establishing congressional investigating commissions which are to be composed of two senators, two representatives and three other persons to be selected jointly by the President of the Senate and the Speaker of the House from a panel appointed by the President and the Senate. ${ }^{73}$

Although the legislature may well utilize commissions to conduct inves-

69 Id. at 243.

70 For reforms in committee procedure favored by the Commonwealth Club see 27 THE COMOMON WEALTR 161 .

i1 BARRET, supra note 2. The federal committee takes the same view of its functions. Carr, Investigations in Operation: The Un-American Activities Committee, $18 \mathrm{U}$. of CHI. L. REv, 598 (1951). 1951).

7260 STAT. 237, 5 U.S. C. \$§ 1001-11 (1946), as amended, 5 U. S. C. §§ 1001-11 (Supp.

73 Galloway, Congressional Investigations: Proposed Reforms, 18 U. OF CHI. L. Rev. 478, 487 (1951), and Finer, Congressional Investigations: The British System, id. at 521 . 
tigations respecting un-American activities it would be dangerous to deny it the right to hold its own inquiries. Occasions may arise when such a legislative inquiry will be advantageous.

Even under the best of circumstances in the search for truth a committee will uncover much that is irrelevant and untrue; the task is to prevent half-baked data from being bandied about. Success in that respect will not cure all the problems involved in protecting the individual against the legislature, but it will help. It will leave open such questions as how far an individual can be forced to incriminate himself and how far fishing expeditions can invade his privacy. But it should tend to eliminate abuses of the investigatory committees as well as mitigate the damage they do. What reason will a politician have for sensationalism when deprived of an audience?

Secret sessions, at least on occasion, may help solve the problem but they do not provide the complete answer. The reports of the California UnAmerican Activities Committee repeat many of the objectionable features of the hearings. Moreover secrecy has its own disadvantages. Many believe that the quickest way to cure wrongful tactics is to expose them to the light. The smearing tactics which injure individual victims will sooner or later lose votes for the perpetrators.

Some help may come from newspapers and press associations in "playing down" the activities of publicity-conscious committees, but not too much should be expected. Editors approach the task of publishing "news" with an almost fanatical fervor. News is the unusual and charges of disloyalty receive immediate attention. As one editor remarked: "It would be a sad day indeed in the United States were disloyalty ever to become so common that it would no longer be regarded as news." Thus, a liberal editor published a lie. He said: "I know it is a lie, but I must print it because it is spoken by a prominent public official." ${ }^{44}$ The charge appears, in the case of the ordinary editor, featured on page one. It may later be denied, retracted or disproved, but "as a rule, denials receive less attention than the charges." ${ }^{75}$ Proof of innocence may come so late as to be almost unrelated to the original charges.

In the case of legislative investigations it is generally believed that a newspaper may repeat the most irrational charges and gossip as long as it is providing a fair report of a legislative investigation and acts without malice. The privileged status given reports of legislative proceedings protect the paper against the well-established rule that one who repeats a defamatory remark is liable as well as the one who originates it.

Possibly some protection for the individual may come from a revision of the law of libel with respect to the activities of legislative investigating committees. It has been suggested that witnesses giving libelous testimony be deprived of their protection against suit. ${ }^{\top \epsilon}$ Another proposal would permit legislators to be brought to court and provide that the government pay

74 Dilliard, Congressional Investigations: The Role of the Press, 18 U. OF CHr. L. Rer. $585,586,587$ (1951).

T5 $I d$. at 587.

76 Galloway, supra note 73, at 494 . 
the bill for damages. ${ }^{77}$ Much as one is tempted to applaud such solutions they may tend to deprive the lawmaking body of data it needs by inhibiting fearful witnesses and timid legislators.

These difficulties disappear if those who disseminate the libel are deprived of the privilege they now enjoy, but problems involving the freedom of the press develop. A modification of both the law of libel and the retraction statute might reconcile the conflicting interests. Newspapers and radio broadcasters might retain their present privilege to report the activities of legislative investigating committees provided that they give equally fair and complete coverage to any denials submitted to them within a prescribed time."after knowledge of the publication or broadcast of the statements claimed to be libelous." Such a procedure should permit the press full freedom to disseminate a fair account of the news and still permit those who have been unfairly attacked to protect themselves against individual busybodies who further injure them.

In any event the legislature should give those whose good name has been unjustly tarnished a right to appeal to the courts. Even the best of committees may inadvertently be misled by its witnesses. It should not be asked to determine the guilt or innocence of all those who may be named as subversive. Yet the legislature can readily provide that those who have been smeared in any legislative mvestigation may resort to the courts and obtain, if the evidence warrants, a declaratory judgment establishing their loyalty. Courts have the facilities and training to conduct such inquiries. Legislative investigating committees do not.

There remains the task of finding some one to lead the fight for these or other reforms. So far the record has been rather depressing. Although the League of Women Voters and some church groups placed their opposition to the Tenney committee's activities on the high ground of principle, the California State Bar protested only when lawyers were concerned, the University of California faculty when professors were involved, the Democrats when their leaders were attacked. Even then the opposition might have been insufficient if Tenney had not run afoul of Art Samish, the lobbyist, and the old age pension forces led by George $\mathrm{H}$. McClain. ${ }^{78}$

Among those who seem to be more logical defenders of our liberties than Art Samish or George McClain, the State Bar ranks high. Its members know how important proper procedure is to the maintenence of substantive rights. They know that the ruthless process of the Court of the Star Chamber once utilized for good ends was eventually perverted to bad ends. They know that while legislative investigating committees are investigating subversives in the Fifties, the target in the Thirties was "economic royaliststhe malefactors of great wealth," and tomorrow it may be someone else. The State Bar already has a committee on legal ethics, a committee on judicial ethics. Should it not create a committee on legislative ethics?

Some will disapprove because Communists may benefit, but the Bar has (1951).

77 Congressional Investigations: Defamation Immunity, 18 U. of CHI. L. REV. 591, 592

T8 BARRETT at $307,316-7,325$. 
a record of courage in defending fair play for all. John Adams defended the British Redcoats after the Boston Massacre. It was Charles Evans Hughes who in 1920 fought to restore sanity when the New York Assembly refused to seat five duly elected Socialists. It was another former Republican candidate for president, Wendell Wilkie, who successfully defended Communist Schneiderman before the Supreme Court in 1943. None of them approved of the politics of those for whom they acted. They merely wished to uphold our American system of justice.

In conclusion it seems pertinent to repeat that the fundamental issue is whether Gresham's law applies to civil liberties. What do we gain if we win the battle agamst subversives but lose the war for freedom? America has long prided itself on Yankee ingenuity. Do we have to confess that it now fails us; that we must protect ourselves against un-American activities in an un-American way? 